Meta

Journal des traducteurs

Translators' Journal

\title{
Assessment In Translation Studies: Research Needs
}

\section{Nicole Martínez Melis et Amparo Hurtado Albir}

Volume 46, numéro 2, juin 2001

Évaluation : paramètres, méthodes, aspects pédagogiques /

Evaluation: Parameters, Methods, Pedagogical Aspects

URI : https://id.erudit.org/iderudit/003624ar

DOI : https://doi.org/10.7202/003624ar

Aller au sommaire du numéro

Éditeur(s)

Les Presses de l'Université de Montréal

ISSN

0026-0452 (imprimé)

1492-1421 (numérique)

Découvrir la revue

Citer cet article

Martínez Melis, N. \& Hurtado Albir, A. (2001). Assessment In Translation Studies: Research Needs. Meta, 46(2), 272-287. https://doi.org/10.7202/003624ar

\section{Résumé de l'article}

Hormis quelques exceptions, la plupart des travaux consacrés à l'évaluation en traduction ne tiennent compte que d'un seul domaine de la traduction, celui des textes littéraires et sacrés. Or, ce champ de recherche concerne aussi deux autres domaines qui, comme le précédent, ont leurs particularités : l'évaluation dans l'exercice de la profession et l'évaluation dans l'enseignement de la traduction. Après avoir procédé à une délimitation de ces trois domaines, nous proposons une analyse de la notion d'évaluation en traduction afin d'en déterminer pour chaque domaine les objets, les types, les fonctions, les objectifs et les moyens en rapport avec l'évaluation. Nous abordons en- suite la question de la compétence en traduction, c'est-à-dire les connaissances et les aptitudes requises, les notions de problème et d'erreur de traduction. Nous discutons ensuite des principes qui devraient soustendre toute évaluation. Enfin, nous proposons des instruments d'évaluation et nous suggérons des orientations de recherche en évaluation dans la didactique de la traduction, qui est à notre avis un aspect des études traductologiques encore trop négligé.
Ce document est protégé par la loi sur le droit d'auteur. L'utilisation des services d’Érudit (y compris la reproduction) est assujettie à sa politique d'utilisation que vous pouvez consulter en ligne.

https://apropos.erudit.org/fr/usagers/politique-dutilisation/ 


\title{
Assessment In Translation Studies: Research Needs
}

\author{
NICOLE MARTÍNEZ MELIS
}

AMPARO HURTADO ALBIR

Universitat Autònoma de Barcelona, Barcelona, Spain

\begin{abstract}
RÉSUMÉ
Hormis quelques exceptions, la plupart des travaux consacrés à l'évaluation en traduction ne tiennent compte que d'un seul domaine de la traduction, celui des textes littéraires et sacrés. Or, ce champ de recherche concerne aussi deux autres domaines qui, comme le précédent, ont leurs particularités: l'évaluation dans l'exercice de la profession et l'évaluation dans l'enseignement de la traduction. Après avoir procédé à une délimitation de ces trois domaines, nous proposons une analyse de la notion d'évaluation en traduction afin d'en déterminer pour chaque domaine les objets, les types, les fonctions, les objectifs et les moyens en rapport avec l'évaluation. Nous abordons ensuite la question de la compétence en traduction, c'est-à-dire les connaissances et les aptitudes requises, les notions de problème et d'erreur de traduction. Nous discutons ensuite des principes qui devraient soustendre toute évaluation. Enfin, nous proposons des instruments d'évaluation et nous suggérons des orientations de recherche en évaluation dans la didactique de la traduction, qui est à notre avis un aspect des études traductologiques encore trop négligé.
\end{abstract}

\section{ABSTRACT}

On the whole, most research into assessment in translation only concentrates on one area-evaluation of translations of literary and sacred texts - and other areas are ignored. In fact, this field of research includes two other areas, each with its own characteristics: assessment of professionals at work and assessment of trainee translators. Starting with this presupposition, we describe the three areas and analyze the notion of translation assessment, so as to define the characteristics of each area: objects, types, functions, aims and means of assessment. Next, we discuss the question of translation competence, and the concepts of translation problems and translation errors, in order to reach a general principle that should be applied in all assessment. Finally, we suggest assessment instruments to be used in teaching translation and make suggestions for research in assessing translator training, an area that has long been neglected and deserves serious attention.

\section{MOTS-CLÉS/KEYWORDS}

assessment, literary translation, translation competence, translation problems, translator training

\section{Assessment in Translation Studies}

\subsection{The Search for Criteria}

For centuries, translations have been carried out on the basis of essentially stylistic criteria or according to the translation method used (literal or free). Historically, many of the texts on translation have been in the form of commentaries by authors 
on translations performed by other authors; the debate on the translation method used is a constant, in which the dichotomy between literal translation, on the one hand, and free translation, on the other, is absolutely central. Nowadays, and despite the enormous advances in literary criticism, translation criticism is either non-existent or, if practised at all, is carried out in a subjective, undisciplined/ad hoc fashion.

Horguelin (1985) gives a brief analysis of the development of contemporary translation evaluation. He observes that translation evaluation has long been a very subjective exercise, and that only recently signs of a more methodical approach have appeared. According to Horguelin, in the contemporary period the appreciation of quality in translation has ceased to be a debate based on general, vague criteria and has focused on a search for more objective systems of evaluation, ranging from simple value scales to sophisticated global models. He traces the beginnings of this search back to the 1959 FIT Congress, which centred on the theme of quality in translation and which raised the importance of taking into account the purpose of the translation, rather than abstract criteria, as well as the need for translation criticism to become a specialised sector of literary criticism.

\subsection{Three Areas Of Evaluation}

\subsubsection{The Evaluation of Published Translations}

Translation evaluation is relevant in three areas of translation (Martínez Melis 1997): the evaluation of published translations, the evaluation of professional translators' work and evaluation in translation teaching.

We are referring to the translation of literary texts (poetry, novels, essays, etc.) and sacred texts, the field to which evaluation in translation has traditionally been confined. This may involve the evaluation of a single translation of a text or the comparison of several translations of an original text. The former is concerned with translation criticism in the sense in which that term has generally been understood, while the latter is concerned with comparative translation study which may be synchronic (between translations done during the same period of time) or diachronic (translations carried out at different points in time) or multilingual (comparing translations into various languages of a single original text).

The aim of this type of evaluation is to judge a translation, to discuss its merits and demerits, and, sometimes, to propose solutions. In this case, the evaluation debate is closely linked to notions of fidelity and quality in translation (Hurtado Albir 1990): accordingly, evaluation criteria may change, depending on the period, aesthetic taste, literary conventions, the prevailing translation method (literal or free), and others.

Outside the academic context, the evaluation of published translations is generally carried out in the absence of any objective criteria of analysis and, sometimes without even a detailed comparison between the translation and the original text. In some translation prizes the jury takes only the translation into account, without consulting the original text. However, in recent decades the academic world has seen the gradual introduction of objective criteria into translation evaluation; moreover, the progress seen in Translation Studies has led to a better understanding of how translation works, as well as to the proposal of analytical categories. 
Thus, we currently have a substantial and varied body of proposals for the analysis of translations, although only a few (House, Larose) have been formulated explicitly for translation evaluation:

- the technical procedures proposed by Vinay and Darbelnet (1958);

- the dynamic equivalence criteria proposed by the Bible translation scholars (Nida and Taber 1969; Margot 1979) based on the importance of reception;

- the situational dimensions put forward by House (1981) with functionalist criteria;

- the contextual dimensions put forward by Hatim and Mason (1990);

- the categories derived from the polisystem theory (Toury 1980; Rabadán 1991);

- the integrated peritextual and textual model proposed by Larose (1989);

- the sociocultural norms and parameters proposed by Hewson and Martin (1991);

- the relationship between intratextual and extratextual factors proposed by Nord (1988) from a functionalist perspective.

These categories are very diverse, and are of differing degrees of usefulness and levels of analysis: some merely provide a metalanguage for identifying translation solutions (the technical translation procedures), while others are useful in analysing microstructural elements (Larose), and yet others are of use in contextualising translations (Rabadán). However, there is still no operative model of analysis for translation evaluation that is capable of bringing together textual, contextual and functionalist criteria, and that has been sufficiently validated by means of empiricalexperimental research.

\subsubsection{Evaluation in Professional Translation Practice}

This type of evaluation deals with the evaluation of the individual translator for professional reasons (the application for a post or membership of a professional association, to assess the translator's cost-effectiveness, etc.) In this case, the translated texts are technical, economic, scientific, legal, commercial, etc., and account for the vast majority of translations in the world today. Obviously, these texts can also be evaluated for the purpose of research or for pedagogical reasons in the academic or teaching context. This type of translation evaluation is carried out by translation agencies, companies, international organisations.

When it comes to judging these translations, in addition to the criteria of fidelity and quality, other factors such as effectiveness and profitability come into play. In this context, scoring scales and surveys on quality assessment are of great importance.

Perhaps the greatest development in research in this field has taken place in Canada, since the 1970s, with an emphasis on the search for correcting scales (to determine error types) and rating scales (to measure translation quality): the CTIC scale (Conseil des traducteurs et interprètes de Canada), and the SICAL scale (Système canadien d'appréciation de la qualité linguistique) in its different versions. The SICAL line of research includes the studies carried out by Gouadec $(1981,1989)$; this author proposes a complex scale according to which it is possible to identify 675 error types (300 lexical, 375 syntactic).

\subsubsection{Evaluation in Translation Teaching}

In the context of translation teaching, reflection has basically focussed on the search for correcting and rating scales (Delisle 1993; Hurtado 1995), on how errors in translation operate (Nord, 1996; Kussmaul 1995; Pym 1993; Gouadec 1981 and 1989) and 
on the notion of the translation problem, which is closely linked to that of translation error (Nord 1988; Presas 1996).

\subsection{Research on Evaluation in Translation Studies}

Progress in the research on evaluation in Translation Studies is directly related to the development of other fields of research. First, two fundamental questions need to be answered: what is evaluation, and what is being evaluated? Defining the notion of evaluation belongs to the realm of Education Science. The object of evaluation (what is being evaluated) ultimately takes us back to the competencies required in order to carry out a good translation.

Second, we need to consider how the evaluation is conducted. In other words, it is necessary to define assessment criteria, and to develop evaluation procedures and instruments.

\section{Defining the Notion of Evaluation in Translation}

\subsection{The Notion of Evaluation}

\subsubsection{Evolution}

The notion of evaluation has long been the object of study in Education Science. The field of evaluation has gradually broadened to the extent that it now encompasses not only examinations but also the educational system as a whole (students, teaching programs, curricula, etc.) and even extra-academic areas (company evaluation, etc.).

In the pedagogical context, evaluation has traditionally been equated with measuring in order to judge; according to this perspective, the evaluator is therefore a judge, while the person evaluated has to submit to the evaluator's authority, which is not always either just or objective. Thus, docimology has done pioneering work in questioning the value of examinations, seeking objectivity through the training of evaluators and by developing evaluation instruments.

Evaluation was later to become an integral part of pedagogical practice, no longer concerned only exclusively with examinations. Thus, the student's knowledge was evaluated, but so too was the functioning of both, the student and the school system in general. A more active attitude was encouraged on the part of the student and self-evaluation was incorporated into the learning process.

According to the latest research trends, it is the subjects (both the trainer and the trainee), rather than the objects of knowledge (the objectives and contents of the teaching program) that are the real protagonists of evaluation. Evaluation has become more creative; various evaluation models have been formulated, not only for the purpose of instruction (assimilation of the program content) but also for the purpose of education (development of individual aptitudes).

The following section presents a classification of the different evaluation models.

\subsubsection{Models}

The various existing models can be classified into two paradigms (Bonniol and Vial, 1997): measurement evaluation (evaluation as measurement) and management evaluation (evaluation as management ). Each model has several currents. 


\section{Evaluation as measurement}

These are models whose aim is to measure and which are not included in pedagogical practice. There are three such models.

1) The Determinist model, which studies the phenomena, causes and effects of training on the trainee.

2) The Docimology model, which corresponds to the study of examinations; this is concerned with objectivity in correcting and grading. Two currents can be distinguished: docinomy, which studies the factors that influence scoring; doxology, which studies the evaluator.

3) The Metrics model, which devises school tests and is concerned with the reliability of measurements. Two currents may be distinguished: psychometrics, concerning individuals; edumetrics, concerning data.

\section{Evaluation as management}

These models incorporate evaluation as one more element in pedagogical practice; the purpose is not merely to measure but also to improve. Four models can be distinguished:

1) The Learning by objectives model, which focuses on objectives (general, intermediate, specific) and seeks to rationalise the educational act. The evaluee begins to play a role in evaluation.

2) The Structuralist model, which is concerned with the school structure of the teacher and the student. The class in general is considered as a macrostructure and a specific class is considered as a microstructure; the pedagogical and evaluation resources are also being considered as structures. The social repercussions of evaluation are analyzed and evaluation practice from the workplace, such as observation and listening, is introduced in the classroom.

3) The Cybernetic model, whose chief function is to verify that knowledge has been acquired. According to this model, training is seen as a machine which has one essential function: to make the program understood. The idea of feed-back is introduced: if the student has not assimilated the program, he must go back and work through it again.

4) The Systemist model, according to which the main function of evaluation is to produce something (a task, a change, etc.) and this production is an aid to the learning process. A highly active role is given to the evaluee, who may also be the evaluator; self-assessment plays an important role (self-assessment understood here not merely as the individual awarding himself a particular grade, but also as being aware of the result of the work carried out and of the process followed). Study is carried out on the relationship between the end-product, the process followed and the procedure (the type of task that has to be produced). This model includes the évaluation formatrice (assessment-based training) which gives high priority to the student's participation throughout the evaluation process, encouraging awareness and autonomy. This model is the result of research carried out at the Marseilleveyre Institute in Marseilles between 1974 and 1977.

The following chart shows the two paradigms with their different models.

FIGURE 1

Traditional evaluation models (Martínez Melis 1997: 47, according to Bonniol and Vial 1997)

\begin{tabular}{|l|l|}
\hline Evaluation as measurement & Evaluation as management \\
\hline 1. The determinist model & 1. Learning by objectives \\
\hline 2. Docimology: docinomy and doxology & 2. The structuralist model \\
\hline 3. Metrics: psychometrics and edumetrics & 3. The cybernetic model \\
\hline 4. The systemist model & \\
\hline
\end{tabular}




\subsubsection{Objects Evaluated}

As we have seen, the present concept of evaluation in Education Science not only focuses on the end-product, but also on the process. Moreover, it is concerned with people (students, teachers, and professionals in all fields), as well as with teaching programs, curricula, training centres and companies.

Curricular evaluation emerged as a specialised branch of research in the 1960s. This type of research can include widely differing objects of study such as: organisational and management modes in training, methods of teaching and of evaluating students' work, teacher intervention and animation strategies, the process whereby teaching materials are appropriated and exploited, the types of initial and ongoing training of teachers, the relationship between learning at school and the extra-academic environment.

\subsubsection{Functions}

Three functions of evaluation can be distinguished: diagnostic (or prognostic), summative and formative.

\section{Diagnostic function}

This type of evaluation allows a diagnosis of the student's potential to be carried out; in other words, it brings to light the student's abilities and shortcomings, and is performed before a learning process begins. It can be used as a level-placement tool, as a means of determining whether or not the student may follow a given course of study (entrance test) or to ascertain the cause of any deficiencies in the student's learning process.

\section{Summative function}

This is used to determine the end results and to judge the knowledge acquired, as well as to determine whether or not the objectives have been achieved. It is compulsory and is performed at the end of the learning process, usually by means of an examination, in order to judge and make a decision (whether or not the student is to be admitted to a higher level, awarded a diploma).

Two types of summative evaluation can be distinguished (Prégent, 1990): normative (students are compared, thus allowing a classification to be established) and criteria-based (the evaluation is carried out on the basis of pre-established criteria).

This type of evaluation, therefore, raises the problem of data gathering and the construction of reliable measuring instruments that are properly adapted to what is being evaluated.

\section{Formative function}

Its main objective is to obtain information for the purpose of training. This idea was proposed in 1967 by Scriven, in opposition to summative evaluation; since that time, it has occupied an increasingly significant place in pedagogical resources as a whole. The information can be found in the results (neobehaviourist approach) or in the student's working process (cognitivist approach).

According to Abrecht (1991), the most important features of the formative function are as follows:

1) It is intended primarily for the student who, as a result of awareness, becomes actively involved in his own learning process.

2) It is totally integrated in the learning process.

3) It is flexible and plural, since it has to be adaptable to individual situations. 
4) It is equally concerned with processes and results.

5) The data that it gathers lead to retrospection. It allows difficulties to be observed and traced back to their sources. It does not pass judgement, but rather seeks to understand in order to solve problems.

6) It is also intended for the teacher, because it enables him to make his teaching effective and flexible.

\subsection{Assessment in Translation: Objects, Types, Functions, Means and Aims}

Taking into account the various contributions to research on assessment that we have outlined above, it is possible to give a fuller picture of assessment in translation: the various objects of study, the type of assessment to be carried out, the function it is to perform, the means that can be used and the objective to be pursued in each case. The following chart shows this classification.

FIGURE 2

Assessment in translation (adapted from Martínez Melis 1997: 156)

\begin{tabular}{|c|c|c|c|}
\hline & $\begin{array}{c}\text { PUBLISHED } \\
\text { TRANSLATION }\end{array}$ & $\begin{array}{l}\text { PROFESSIONAL } \\
\text { TRANSLATION }\end{array}$ & $\begin{array}{l}\text { TRANSLATION } \\
\text { TEACHING }\end{array}$ \\
\hline OBJECT & $\begin{array}{l}\text { translation of literary } \\
\text { and sacred texts }\end{array}$ & translator competence & $\begin{array}{l}\text { student translator } \\
\text { competence } \\
\text { study plans } \\
\text { programs }\end{array}$ \\
\hline TYPE & $\begin{array}{l}\text { product assessment } \\
\text { qualitative assessment } \\
\text { qualitative assessment } \\
\text { quantitative assessment }\end{array}$ & $\begin{array}{l}\text { product assessment } \\
\text { quantitative assessment } \\
\text { procedure assessment }\end{array}$ & $\begin{array}{l}\text { product assessment } \\
\text { process assessment } \\
\text { qualitative assessment }\end{array}$ \\
\hline FUNCTION & summative & $\begin{array}{l}\text { summative } \\
\text { formative }\end{array}$ & $\begin{array}{l}\text { diagnostic } \\
\text { formative } \\
\text { summative }\end{array}$ \\
\hline AIM & $\begin{array}{l}\text { informative } \\
\text { advertising } \\
\text { speculative } \\
\text { pedagogical }\end{array}$ & $\begin{array}{l}\text { economic-professional } \\
\text { speculative }\end{array}$ & $\begin{array}{l}\text { academic } \\
\text { pedagogical } \\
\text { speculative }\end{array}$ \\
\hline MEANS & evaluation criteria & $\begin{array}{l}\text { non-literary translation } \\
\text { evaluation criteria } \\
\text { correcting scales } \\
\text { grading scales, tests, etc. }\end{array}$ & $\begin{array}{l}\text { translations } \\
\text { evaluation criteria } \\
\text { correcting criteria } \\
\text { grading scales, tests, } \\
\text { exercises, } \\
\text { questionnaires, etc. }\end{array}$ \\
\hline
\end{tabular}

\subsubsection{Assessment of Published Translations}

In this case, assessment is carried out on texts which are essentially literary, in the broadest sense of the word (novel, theatre, essay, etc.), and sacred texts. What is assessed here is the product, that is to say the translation that has been carried out (an analysis of the process followed by the translator could also be considered in research). 
The assessment is qualitative, because it is quality that is at stake here, and it has a summative function because it involves passing judgement. Objective and reliable assessment criteria must be used [see below 4.2]. This type of assessment may be performed for the purposes of information (independent criticism of a translation in the media), advertising (if the appraisal is used to sell a product), speculative (if it is to be used in Translation Studies research), or for pedagogical reasons (as when literary texts are used in class).

\subsubsection{Assessment in Professional Practice}

In this case, the object of study is the professional competence of the translator. Assessment must take into account the result (the actual tanslations carried out), but also the knowledge, skills and aptitude of the translator. The assessment focuses not only on quality, but also on quantity, since the translator's output is one of the key factors. The function of assessment is summative, since both judging the candidate and coming to a decision are involved in personnel selection. However, it may also be formative to the extent that a translator can learn from his mistakes following the assessment/revision process. The assessment may involve use of translations, assessment criteria, correcting and grading scales, as well as aptitude tests, etc [see below 5]. Its aim is twofold: economic-professional (in the case of recruiting a translator or studying a translator's profitability potential), or speculative (as in the case of scales studies).

\subsubsection{Assessment in Translation Teaching}

In this case, the object of study is the student's translator competence, as well as the study plan and the program. Student assessment is concerned with the product and the individual process followed, as well as the procedures used (observation of the appropriate principles). The quality, as well as the quantity (performance), of the product can be assessed. The three functions of assessment (diagnostic, summative and formative) are operative in this field. Assessment requires translations, assessment criteria, grading and correcting scales, questionnaires, exercises, etc. [see below 5]. The aim of assessment may be academic (since it fulfils the need for selection required by the institution concerned), pedagogical (since it forms part of the training process) and speculative (because all reasoned and conscious assessment may have consequences for theory).

\section{Translation Competence}

What is being assessed? This is the second key question in the debate on assessment in translation. In order to answer this question, we must consider the elements that define the competence of a good translator, the different levels of competence, and progression in the acquisition of that competence (levels, threshold of acceptability, etc.). It is therefore necessary to define what constitutes translation competence (the knowledge and the skills it involves, the subcompetencies it entails) and how it can be acquired.

Unlike other disciplines, in which numerous research studies have been carried out on the functioning of expert knowledge and how it is acquired, the history of research in Translation Studies is both short and lacking in empirical studies. 
As a guideline for research that is required in this field, we present the hypothesis which provides the starting-point for the PACTE (Process of the Acquisition of Translation Competence and Evaluation) research group in designing the empirical experimental research that it is carrying out on translation competence and its acquisition. Researchers in the PACTE group are: A. Beeby, L. Berenguer, D. Ensinger, O. Fox, A. Hurtado Albir, N. Martínez Melis, W. Neunzig, M. Orozco and M. Presas. The holistic, dynamic model proposed by PACTE considers translation competence to be the underlying system of knowledge, aptitudes and skills necessary in order to be able to translate. It consists of six subcompetencies (PACTE 1998 and 2000):

1) Communicative competence in both languages. Comprehension in the source language and expression in the target language.

2) Extralinguistic competence. Knowledge of the theory of translation, bicultural knowledge, encyclopaedic and thematic knowledge.

3) Transfer competence. The ability to perform the entire process of transfer from the original text to the final text: comprehension, deverbalisation and separation of the two languages (control over interference), re-expression and definition of the translation project (selection of the most appropriate translation method).

4) Instrumental/professional competence. Knowledge and skills relating to professional translation practice: knowledge of documentation sources, new technologies, the labour market, professional conduct.

5) Psychophysiological competence. The ability to apply psychomotor, cognitive and attitudinal resources: psychomotor competences and skills in reading and writing, cognitive faculties (memory, attention, creativity, logical thought, etc.) as well as psychological attitudes (intellectual curiosity, perseverance, rigour, critical acumen, awareness of and confidence in one's own ability, etc.).

6) Strategic competence. Conscious and subconscious, verbal and non-verbal individual procedures used to solve problems encountered during the translation process. This competence is used in detecting problems, making decisions, correcting occasional errors or deficiencies in any of the other subcompetences. Included here are comprehension strategies (differentiating between main and secondary ideas, establishing conceptual relationships, searching for information, etc.), reformulation (paraphrase, back-translation, reformulating aloud, avoidance of faux amis/false cognates/calques, etc.), documentation (establishing an order of inquiry, knowing how to select information, etc.).

All these subcompetencies are inter-connected and together constitute what we refer to as translation competence. Here transfer and strategic competencies play a vital role: the former, because it brings together all the other sub-competencies, and the latter, because it is used in making up with the deficiencies and solving the problems arising from any of the other sub-competencies.

The definition of translation competence and the process by which it is acquired is of supreme importance in teaching translation since it provides the guidelines in establishing the learning objectives and the pace of teaching (definition of levels and thresholds of acceptability).

\section{Assessment Criteria in Translation}

\subsection{Defining the Notion of Translation Problem and Error}

In order to establish assessment criteria in translation, we first have to define two concepts which are central to research on assessment in translation: the concept of translation problem and the concept of translation error. 


\subsubsection{Translation Problems}

Nord (1991: 151) defines the translation problem as an objective problem which every translator [...] has to solve during a particular translation task.

The problems encountered by the translator are varied: linguistic, extralinguistic, transfer problems. A working classification of these problems can be made in relation to the particular competence that the translator needs to mobilise. According to the PACTE list of sub-competencies, they may be classified as follows:

1) linguistic (lexical, syntactic, textual)

2) extralinguistic (cultural, thematic, encyclopaedic)

3) transfer problems (difficulty in finding the dynamic equivalence)

4) psychophysiological (relating to creativity, logical thought)

5) professional/instrumental (deriving from the translation brief, or documentation difficulties).

Because of its role as a regulating mechanism, compensating for deficiencies in the other sub-competencies and solving the problems that arise, it is obvious that strategic competence is crucial in dealing with translation problems.

However, there is a clear need for research that can provide empirical data on the problems encountered by the translator and the mechanisms the translator uses solving them, as well as on problem-solving in the translation competence acquisition process.

\subsubsection{Translation Errors}

Here too, we lack broad-based empirical studies that can validate a typology of errors, the greater or lesser degree of occurrence of specific errors in specific translation tasks, the level at which they occur in learning, etc.

\section{Typology of errors}

In our view, the main questions that need to be taken into account in translation error classification are as follows:

1) The difference between errors relating to the source text (opposite sense, wrong sense, nonsense, addition and suppression) and errors relating to the target text (spelling, vocabulary, syntax, coherence and cohesion) (Kupsch-Losereit, 1985; Delisle, 1993; Hurtado Albir, 1995, 1999).

2) The difference between functional errors and absolute errors. The functional error has to do with the transgression of certain functional aspects of the translation project, whereas the absolute error is independent of the specific translation task and involves an unjustified infringement of the cultural or linguistic rules, or of the use of a given language (Gouadec, 1989; Nord, 1996).

3) The difference in individual translators between systematic errors (recurrent) and random errors (isolated); see Spilka's distinction $(1984,1989)$ between error and mistake.

4) The difference between errors in the product and errors in the process.

\section{Seriousness and impact of the error}

An extremely important element in the debate is the analysis of the importance and frequency of the error. Some authors classify errors on a scale of more to less serious: in Nord's opinion (1996), the most serious are pragmatic errors, followed by cultural and linguistic errors; Larose (1989) considers that the seriousness of the error depends on 
the textual level at which it occurs (superstructure, macrostructure, microstructure): the higher the level, the more serious the error. Other authors consider that errors of sense relating to the original text (opposite sense, wrong sense, nonsense) and those which affect the coherence and cohesion of the target text are the most serious (Dancette, 1989; Hurtado, 1995); Honig (1987) and Gouadec (1989) maintain that the seriousness of the error depends on the extent to which it infringes on the effectiveness of the target text.

In our opinion, it is not the nature of an error that determines its gravity. This can only be analyzed from a functionalist perspective which takes into account its importance in relation to:

1) The text as a whole (whether it affects a key idea or a subordinate idea);

2) The coherence and cohesion of the target text:

3) The degree of deviation from the sense of the original text, particularly if this deviation is likely to remain undetected by the reader of the translation:

4) The functionality on a communicative level of the target text (infringement of texttype conventions, etc.);

5) Adverse consequences regarding the purpose of the translation (resulting in the failure to sign a contract, sell a product, etc.).

\section{Etiology of the error}

Another fundamental aspect, particularly in translation teaching, is the analysis of the causes of the error. This is what is referred to as the etiology of the error: discovering the causes in order to find the remedy.

Gile (1992) distinguishes three causes of errors: 1) lack of knowledge (extralinguistic, in the source and the target language);2) lack of methodology; 3) lack of motivation. In our view, the lack of knowledge and the inadequate application or assimilation of the principles governing translation are the main causes of translation errors. The second of these two aspects, concerning methodology, seems to us to be crucial, since it is related to errors incurred during the translation process. In translation teaching, the error also has a pedagogical function.

Thus, Amparo Hurtado (1993 and 1995) proposes an error-based teaching strategy comprising the following five principles:

1) Diagnosis of the causes in order to establish the appropriate remedial measures.

2) Individual treatment and diagnosis (since not all students commit the same errors) and encouragement of self-assessment.

3) Learning from the error, encouraging self-assessment so that the student is aware of the kinds of errors he/she makes, their causes and how to avoid them.

4) Recognition of the fact each type of error must be treated differently, as regards the remedial measures and grading.

5) Establishment of a progressive application of the correcting criteria, according to the level of learning.

\subsection{Definition of Assessment Criteria in Translation}

As already observed [see above 2.2], it should be remembered that the object of translation assessment is not only the result of translation, but also the translator's competencies and the process followed. Assessment in translation therefore goes beyond the evaluation of particular translations and must take into account other instruments [see below 5]. We shall begin by giving a general outline of the principles which need to be observed in establishing assessment criteria in the field of translation. 


\subsubsection{Assessment Criteria}

We believe that, in order to carry out a fair and objective assessment, the following basic principles should be observed:

1) The evaluator should adhere to some specific criteria and the evaluee should be aware of them (particularly in the case of translation teaching).

2) The assessment criteria depend on the assessment context (published translations, professional translation, translation teaching) and its function (summative, diagnostic, formative). Also, therefore, the need to consider why, for what purpose and for whom the assessment is being carried out.

3) The object of assessment (what is being assessed?) must be clearly defined, as well as the level at which it is being carried out. The evaluator should also consider what he should and what he can evaluate.

4) The evaluator should consider which indicators enable him/her to observe whether or not and to what extent the evaluee possesses the competencies being evaluated.

In the case of teaching translation, it is indispensable that the assessment criteria should be directly related to the learning objectives (Hurtado Albir 1999).

\subsubsection{Ways of Assessing Translations}

According to the degree of sophistication and objectivity of the assessment criteria, we can divide the ways of assessing translations into three groups:

1) Intuitive assessment is subjective, impression-based and does not follow explicit criteria. This is frequently seen in the criticism of published translations. Unfortunately, it is very widespread in teaching and in professional practice.

2) Partial assessment does not take into account the sum total of factors involved in a translation. For example, considering the time spent on checking the translation, assessing only some of the translation problems, taking into account only some of the final translation's good solutions, etc. This type of assessment is practised in the teaching context as well as in the recruitment of professional translators.

3) Reasoned assessment. It is objective, using scales established on the basis of objective criteria which define and assign a value to the error type. Its apparent reliability would seem to indicate that it is the most appropriate type of assessment in all areas of translation. However, it does pose two problems: the time that it takes to develop and apply, and, above all, the fact that a fixed coefficient is usually assigned to each error.

In our view, translation assessment should:

1) Use objective criteria which define error types (scales);

2) Establish the seriousness of the error on the basis of functionalist criteria [see above 4.1.2] without ascribing fixed coefficients to the errors;

3) Also take into account the good solutions in the translation;

4) Adopt a flexible view of assessment, allowing partial assessments to be carried out as necessary.

\section{Instruments of Assessment in Translation}

There is also a need to develop assessment instruments for all areas (published translations, professional practice, translation teaching), functions, levels and specialisations (legal and technical translation, etc). 


\subsection{Scales}

Scales are obviously key instruments in translation assessment (when it is the product that is to be assessed). A distinction should be made between correcting scales and grading scales. The correcting scale establishes and specifies the error types; it corresponds to a preliminary stage in the development of an assessment scale. Its objective is to decide on the elements that are to be taken into account; in the teaching context, it allows the student to become aware of his errors, and is thus an important instrument in formative assessment. The grading scale, moreover, assigns a value to each error; it is therefore useful in awarding grades and is an indispensable instrument in summative assessment.

Accordingly, Delisle (1993) proposes a correcting scale consisting of 46 symbols; although the errors are not presented in any specific order, the scale has the advantage of enabling the student to understand where the errors are and thereby to improve his/her performance. Hurtado (1995 and 1999) proposes a correcting and grading scale in which the errors are ordered and grouped into four categories: 1) inadequacies which affect comprehension of the source text; 2) inadequacies which affect expression in the target language; 3) pragmatic inadequacies; 4) good solutions.

A scale will be more or less complex, depending on the requirements of the translation task that is being assessed. However, when developing a scale, it is advisable to remember the following:

1) It is important to bear in mind the situation in which the assessment is to be carried out: the areas, the function, the type of translation (technical, legal, etc.) and the level.

2) The errors should be classified.

3) Functionalist criteria should be taken into account (see above 4.1.2), Seriousness and impact of the error) when assigning a numerical value to the various types of error; a scale may be very good as far as its specification and classification of errors is concerned, but may be spoilt by a poor numerical rating system.

\subsection{Other Instruments}

In addition to the scales described above, we need to develop instruments for use in summative assessment (examinations of all kinds), diagnostic assessment (entrance tests) and formative assessment (progress verification tests, instruments to ascertain what difficulties occur in the learning process, self-assessment instruments, etc.).

It is commonly believed that all that is required to assess translation competence is that the evaluee should carry out translations: that is to say, that translation is assessed by means of translations. Although translations are an important instrument in assessment, we believe that they may be complemented or replaced by other instruments. Here are a few examples:

1) Translation exercises, analysis, revision and comparison of translations such as: syntactic translation, expanded translation, comparative translation (comparing, analyzing and/or revising different translations of a single original text), translation revision, translation assessment (with or without a scale), reasoned translation (justifying the solution to certain problems), solving isolated problems (whether or not an explanation of the process followed is given).

2) Exercises relating to given aspects of a translation and how it was carried out: deducing the translation brief by examining the original text together with the translation, 
explaining the principles that need to be followed in a particular translation task without actually performing the translation, exercises in documentation search and use of dictionaries, comparison of documentation sources.

3) Multiple-choice tests, questionnaires and interviews to check that the methodological and professional principles, the theoretical content, the extralinguistic knowledge and the psychological aptitudes have been assimilated.

4) Teacher's observation records, student's documentation (linguistic and extralinguistic) records, student self-assessment records, translation diaries (in which the student keeps a record of the problems encountered, errors, documentation sources used, time invested, global evaluation of the results).

All these instruments are very useful in the three assessment functions. Some of them, however, are particularly important in formative assessment (records and diaries, for example), while others are not so valid in some types of diagnostic assessment (for example, performing a translation in an entrance test).

Careful consideration should be given to the manner in which all these instruments should be used in the act of assessment, that is to say, the procedure application (in a group or individually, their sequencing, etc.). See Hurtado Albir 1999, where various assessment exercices are proposed.

\section{Conclusions: Research Perspectives}

In order to develop and validate the importance of increasingly systematic and rigorous translation assessment proposals, we believe that it is necessary to establish in Translation Studies the kind of research and experimental practices which are now commonplace in other disciplines. Thus, following empirical-experimental research criteria, we may test, contrast and measure the assessment results obtained by means of specific instruments (See Waddington 2000, where various scales are experimentally tested.); test assessment criteria; carry out error analysis in order to identify patterns of errors, classify them and establish levels of difficulty, select prototype texts (authentic or otherwise) to illustrate specific translation problems and levels of competence...

All these questions are of vital importance in teaching, since assessment plays a key role in the educational system. We therefore consider it necessary [see Fig. 3]:

1) To research the current situation of assessment in translation teaching: to catalogue the existing bibliography, develop a database on current assessment practices in curricula translator training centers (tests, assessment criteria, programs, etc,), carry out surveys with teachers and students in order to know their views on assessment.

2) To develop assessment procedures and instruments for each of the three functions by means of empirical experimental research, after a preliminary definition of competencies, objectives and progression.

The following chart summarizes all the research still to be carried out in the field of assessment in the educational system. 
FIGURE 3

Proposals for empirical research on assessment in translation teaching (Martínez Melis 1997: 166)

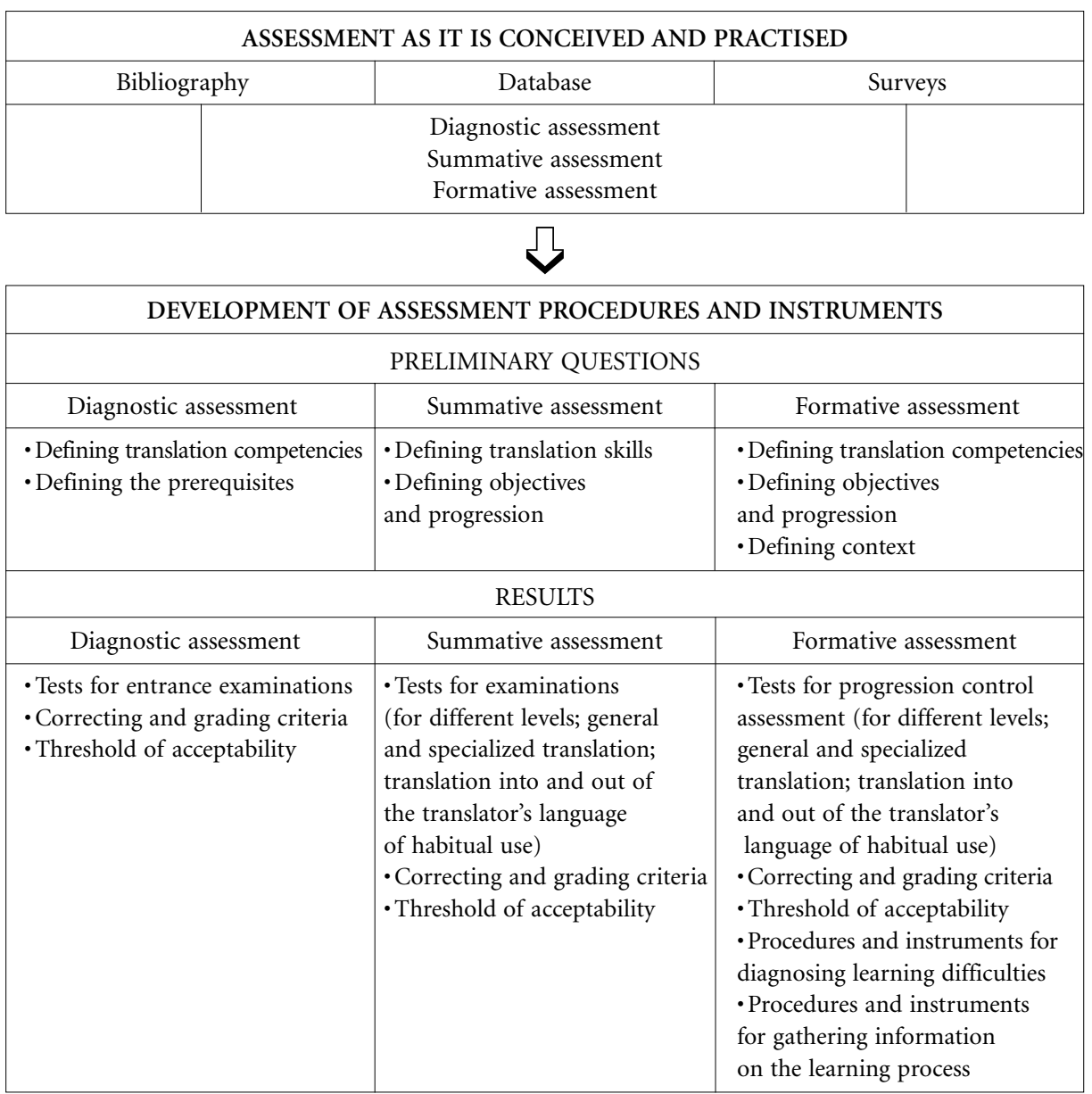

\section{REFERENCES}

Авrecht, R. (1991): L'évaluation formative, une analyse critique, Bruxelles, De Boeck. Bonniol, J. J. and M. Vial (1997): Les modèles de l'évaluation, Bruxelles, De Boeck DANCETTE, J. (1989): «La faute de sens en traduction», TTR, 2-2, numéro spécial «L'erreur en traduction», p. 83-99.

Delisle, J. (1993): La traduction raisonnée, Ottawa, Presses de l'Université d'Ottawa.

GiLE, D. (1983): «Aspects méthodologiques de l'évaluation de la qualité du travail en interprétation simultanée», Meta, 28-3, p. 236-243.

— (1992): «Les fautes de traduction: une analyse pédagogique», Meta, 37-2, p. 251-262.

- (1995): Regards sur la recherche en interprétation de conférence, Lille, Presses Universitaires de Lille.

Gouadec, D. (1981): «Paramètres de l'évaluation des traductions», Meta, 26-2, p. 99-116.

— (1989): «Comprendre, évaluer, prévenir», TTR, 2-2, numéro spécial «L'erreur en traduction», p. 35-54. 
Hatim, B. and I. Mason (1990): Discourse and The translator, London, Longman.

Hewson, L. and J. Martin (1991): Redefining Translation. The Variational Approach, London Routledge.

HöNIG, H.G. (1987): “Wer macht die Fehler?," Translation und interkulturelle Kommunikation (J. Albrecht, H. W. Drescher et al., eds), Frankfurt, Bern, New York und Paris, Lang, pp. 37-45.

Horguelin, P. (1985): Pratique de la révision, $2^{\mathrm{e}}$ éd., Montréal, Linguatech.

House, J. (1981): A model for Translation quality assessment, Tübingen, Narr.

Hurtado Albir, A. (1990): La notion de fidélité en traduction, Paris, Didier Érudition.

- (1994): "Perspectivas de los estudios sobre la traducción," Estudis sobre la traducció (A. Hurtado Albir, ed), 1, pp. 25-41.

- (1995): "La didáctica de la traducción. Evolución y estado actual," Perspectivas de la traducción (P. Hernandez y J. M. Bravo, dir.), Universidad de Valladolid, pp. 49-74.

—, dir. (1999): Enseñar a traducir.Metodología en la formación de traductores e intérpretes, Madrid, Edelsa.

Kupsch-Losereit, S. (1985): “The Problem of Translation Error Evaluation,” Translation in Foreign Language Teaching and Testing (C. Titford and A.E. Hieke, eds), Tübingen, Narr, pp. 169-179.

Kussmaul, P. (1995): Training the Translator, Amsterdam, John Benjamins.

Larose, R. (1989): Théories contemporaines de la traduction, 2 éd., Québec, Presses de l'Université du Québec.

Margot, J. C. (1979): Traduire sans trahir, Lausanne, L'Âge d'Homme.

Martínez Melis, N. (1997): Évaluation et traduction: Cadre de recherche sur l'évaluation dans la didactique de la traduction, thèse, Universitat Autònoma de Barcelona.

NidA, E. and C. TABER (1969): Theory and Practice of Translation, London, United Bible Societies.

Nord, C. (1988): Textanalyse und Übersetzen, Heidelberg, J. Groos Verlag [transl.: (1991): TextAnalysis in Translation, Amsterdam, Rodopi].

— (1996): "El error en la traducción: categorías y evaluación," La enseñanza de la traducción (A. Hurtado Albir, dir.), pp. 91-103.

- (1997): Translating as a Purposeful Activity. Functionalist Approaches Explained, Manchester, St. Jerome

PACTE (1998): "La competencia traductora y su aprendizaje: Objetivos, hipótesis y metodología de un proyecto de investigación," IV Congrés Internacional sobre Traducció, Universitat Autònoma de Barcelona.

- (2000). "Acquiring Translation Competence: Hypotheses and Methodological Problems of a Research Project," Investigating Translation (A. Beeby, D. Ensinger and M. Presas, eds), Amsterdam, John Benjamins.

Piéron, H. (1969): Examens et docimologie, $2^{e}$ éd., Paris, Presses Universitaires de France.

Prégent, R. (1990): La préparation d'un cours, Montréal, Éditions de l'École Polytechnique de Montréal.

Presas, M. (1996): Problemes de traducció i competència traductora, thesis, Universitat Autònoma de Barcelona.

Рyм, A. (1993): Epistemological Problems in Translation and its Teaching, Calaceite, Ediciones Caminade.

RabadÁn, R.(1991): Equivalencia y traducción, Universidad de León.

Snell-Hornby, M. (1988): Translation Studies. An Integrated Approach, Amsterdam, John Benjamins.

SPILKA, I. V. (1984): «Analyse de traduction», La traduction: l'universitaire et le praticien (A. Thomas et J. Flamand), Éditions de l'Université d'Ottawa, p. 72-81.

Toury, G. (1980): In Search of a Theory of Translation, Tel Aviv University.

Vinay, J.-P. et J. Darbelnet (1958): Stylistique comparée du français et de l'anglais, Paris, Didier.

WadDington, C. (2000): Estudio comparativo de diferentes métodos de evaluación de traducción general, Madrid, Universidad Pontificia Comillas. 